\title{
Mitochondria Synergize With P2 Receptors to Regulate Human T Cell Function
}

\author{
Carola Ledderose and Wolfgang G. Junger* \\ Department of Surgery, Beth Israel Deaconess Medical Center and Harvard Medical School, Boston, MA, United States
}

Intracellular ATP is the universal energy carrier that fuels many cellular processes. However, immune cells can also release a portion of their ATP into the extracellular space. There, ATP activates purinergic receptors that mediate autocrine and paracrine signaling events needed for the initiation, modulation, and termination of cell functions. Mitochondria contribute to these processes by producing ATP that is released. Here, we summarize the synergistic interplay between mitochondria and purinergic signaling that regulates $T$ cell functions. Specifically, we discuss how mitochondria interact with P2X1, $\mathrm{P} 2 \mathrm{X} 4$, and $\mathrm{P} 2 \mathrm{Y} 11$ receptors to regulate $\mathrm{T}$ cell metabolism, cell migration, and antigen recognition. These mitochondrial and purinergic signaling mechanisms are indispensable for host immune defense. However, they also represent an Achilles heel that can render

OPEN ACCESS

Edited by:

Davide Ferrari,

University of Ferrara, Italy

Reviewed by:

Fabio Grassi,

Institute for Research in Biomedicine

(IRB), Switzerland

George Hasko,

Columbia University, United States

${ }^{*}$ Correspondence:

Wolfgang G. Junger

wjunger@bidmc.harvard.edu

Specialty section:

This article was submitted to Cytokines and Soluble Mediators in

Immunity,

a section of the journal

Frontiers in Immunology

Received: 07 April 2020

Accepted: 27 August 2020

Published: 29 September 2020

Citation:

Ledderose C and Junger WG (2020)

Mitochondria Synergize With P2

Receptors to Regulate Human T Cell

Function. Front. Immunol. 11:549889.

doi: 10.3389/fimmu.2020.549889 the host susceptible to infections and inflammatory disorders. Hypoxia and mitochondrial dysfunction deflate the purinergic signaling mechanisms that regulate $T$ cells, while inflammation and tissue damage generate excessive systemic ATP levels that distort autocrine purinergic signaling and impair $T$ cell function. An improved understanding of the metabolic and purinergic signaling mechanisms that regulate T cells may lead to novel strategies for the diagnosis and treatment of infectious and inflammatory diseases.

Keywords: P2X4, mitochondria, inflammation, P2X1, P2Y11

\section{INTRODUCTION}

ATP is the main energy carrier of living cells. Therefore, it came as a surprise to many when Geoffrey Burnstock first reported that neurons release a portion of their cellular ATP and that the released ATP acts as a signaling molecule for cell-to-cell communication (1). Subsequently, similar ATP signaling mechanisms were identified in many other tissues and organ systems $(2,3)$. Purinergic signaling enables single cells in a multicellular system to calibrate their individual responses in order to serve the collective interest of the entire organism. Purinergic signaling comprises three basic elements: (i) mechanisms that produce and release ATP into the pericellular space; (ii) purinergic receptors that recognize released ATP and its metabolites and elicit intracellular signals that regulate cell functions; (iii) mechanisms that terminate purinergic signaling by enzymatic breakdown of ATP, cellular re-uptake, or simple diffusion of ATP and its metabolites away from cells.

Intact cells can release ATP via vesicular exocytosis or ATP-permeable membrane channels that include connexin hemichannels, pannexin channels, calcium homeostasis modulator 1, maxi-anion channels, and volume-regulated anion channels $(4,5)$. Of these mechanisms, pannexin 1 (panx1) channels are particularly important in immune cells (6-10). Under basal conditions, resting cells 
release only a small portion of their cellular ATP. However, mechanical stimuli or the ligation of cell surface receptors such as the antigen and chemokine receptors of $\mathrm{T}$ cells rapidly increase cellular ATP release (10-12). While regulated ATP release finetunes cell responses, excessive ATP leakage from dying cells or damaged tissues can act as a danger signal that exacerbates inflammation, impairs $\mathrm{T}$ cell functions, and disrupts immune responses (13-16).

ATP release and its breakdown products defines immune cell functions by autocrine stimulation of three different families of purinergic receptors, namely $\mathrm{P} 1, \mathrm{P} 2 \mathrm{X}$, and $\mathrm{P} 2 \mathrm{Y}$ receptors. Different combinations of these receptors are present on the surfaces of virtually all mammalian cells, including the different immune cell subtypes (17). P1 receptors, which recognize adenosine, comprise four subtypes: A1, A2a, A2b, and A3 receptors. $\mathrm{P} 2 \mathrm{X}$ receptors recognize ATP and consist of seven members (P2X1-7). Human P2Y receptors comprise eight members that recognize a wider range of ligands (18-21). P2Y2, P2Y4, P2Y11, and P2Y13 receptors are activated by ATP; but certain $\mathrm{P} 2 \mathrm{Y}$ receptors also recognize other nucleotides including ADP (P2Y1, P2Y12, P2Y13), UTP (P2Y2, P2Y4, P2Y6), UDP (P2Y4, P2Y6), and UDP-glucose (P2Y14) $(21,22)$. P1 and P2Y receptors belong to the $G$ protein-coupled receptor (GPCR) superfamily, while $\mathrm{P} 2 \mathrm{X}$ receptors are ATP-gated cation channels that facilitate the influx of extracellular $\mathrm{Ca}^{2+}$.

Purinergic receptors differ greatly in their desensitization kinetics and affinities for their individual ligands. The extracellular concentrations of these ligands depend on the activities of ectoenzymes expressed on the cell surface (23). Several different groups of these enzymes have been identified including ectonucleoside triphosphate diphosphohydrolases (ENTPDases), ectonucleotide pyrophosphatases/phosphodiesterases (ENPPs), ecto-5' nucleotidase (CD73), adenosine deaminase (ADA), as well as alkaline phosphatases (23-25). These enzymes are widely distributed among the different immune cell subpopulations (24). CD39 (ENTPD1) that converts extracellular ATP and ADP into AMP, and CD73 that degrades AMP to adenosine are particularly important modulators of purinergic signaling in immune cells $(26,27)$. Once released from cells, ATP and its breakdown products can either diffuse away from cells or be internalized by equilibrative and concentrative nucleotide transporters that are embedded in the cell membrane and return ATP and its breakdown products for recycling and reuse in cell metabolism (28). The distribution patterns of ATP release sites, ectonucleotidases, and nucleoside transporters along with their relative proximity to $\mathrm{P} 1$ and $\mathrm{P} 2$ receptors are important determinants of the purinergic signaling mechanisms that regulate immune cell functions.

\section{P2X1 RECEPTORS MAINTAIN MITOCHONDRIAL METABOLISM OF QUIESCENT T CELLS}

Autocrine purinergic signaling is an important mechanism of immune cell regulation $(17,29-33)$. Human $\mathrm{T}$ cells express
A2a, A2b, A3, P2X1, P2X4, P2X5, and P2X7, as well as all eight P2Y receptor subtypes (34-36). P2X1, P2X4, P2Y11, and $\mathrm{P} 2 \mathrm{X} 7$ receptors have particularly important roles in the regulation of CD4 T cells (10-12, 36-40). Among these receptors, $\mathrm{P} 2 \mathrm{X} 1$ receptors are most sensitive with an $\mathrm{EC}_{50}$ value of 50$1000 \mathrm{nM}$ ATP $(22,41)$. Such ATP levels are well within the concentration range found in the pericellular environment of quiescent $\mathrm{T}$ cells (42). Constitutive ATP release from cells overexpressing $\mathrm{P} 2 \mathrm{X}$ receptors is sufficient to sustain the modest $\mathrm{Ca}^{2+}$ uptake that preserves basal mitochondrial metabolism and ATP synthesis of resting cells (43). P2X1 receptors maintain mitochondrial metabolism in quiescent human CD4 T cells by facilitating cellular $\mathrm{Ca}^{2+}$ influx that sustains basal mitochondrial $\mathrm{Ca}^{2+}$ levels (44). Inhibition of mitochondrial metabolism and interruption of the electron transport chain impairs $\mathrm{T}$ cell migration, indicating that mitochondrial ATP production fuels the purinergic signaling mechanisms needed for immune surveillance and $\mathrm{T}$ cell functions $(12,45)$. Indeed, mitochondrial defects and $\mathrm{T}$ cell suppression are cardinal features of sepsis that correlate with morbidity and clinical outcome (44, 4649). Taken together, these findings suggest that P2X1 receptormediated $\mathrm{Ca}^{2+}$ influx, mitochondrial ATP production, basal ATP release, and autocrine feedback through P2X1 receptors represent a purinergic-metabolic signaling loop that maintains cell metabolism of quiescent $\mathrm{T}$ cells and allows these cells to mount the responses needed for effective host immune defense following chemokine or antigen stimulation (Figure 1A).

\section{P2X4 RECEPTORS AND MITOCHONDRIAL METABOLISM PROMOTE T CELL MIGRATION}

Stimulation of CXCR4, CCR5, CCR7, and other chemokine receptors leads to the recruitment of $\mathrm{T}$ cells to lymphoid organs where cell migration enables them to engage and interact with antigen-presenting cells (APCs) (50-52). Stimulation of CXCR4 by stromal cell-derived factor $1 \alpha$ (SDF- $1 \alpha)$ causes rapid surges of mitochondrial ATP synthesis and panx1-mediated ATP release from CD4 T cells $(12,53)$. The resulting pericellular ATP levels trigger $\mathrm{P} 2 \mathrm{X} 4$ receptors with an estimated $\mathrm{EC}_{50}$ value ranging between 0.5 and $10 \mu \mathrm{M}(22,41)$. Autocrine stimulation of P2X4 receptors promotes waves of $\mathrm{Ca}^{2+}$ influx that further upregulate mitochondrial ATP synthesis to the levels needed for active T cell migration (Figure 1B) (12). P2X4 receptors aggregate in raftlike structures that associate with mitochondria primarily at the front of migrating T cells where localized ATP synthesis fuels pseudopod protrusion and forward movement of the cells. These $\mathrm{P} 2 \mathrm{X} 4$ receptor-driven mechanisms are particularly critical for $\mathrm{T}$ cells that move slowly in order to probe their surroundings for potential antigens (12). Faster moving lymphocytes, however, gather their mitochondria primarily at the uropod where the bulk of ATP may be required to fuel actomyosin motor functions needed for rapid cell migration (45). Inhibition of mitochondrial ATP synthesis, ATP release, or P2X4 receptor signaling impairs the ability of $\mathrm{T}$ cells to polarize and to migrate in response to CXCR4 stimulation $(12,45,53)$. 


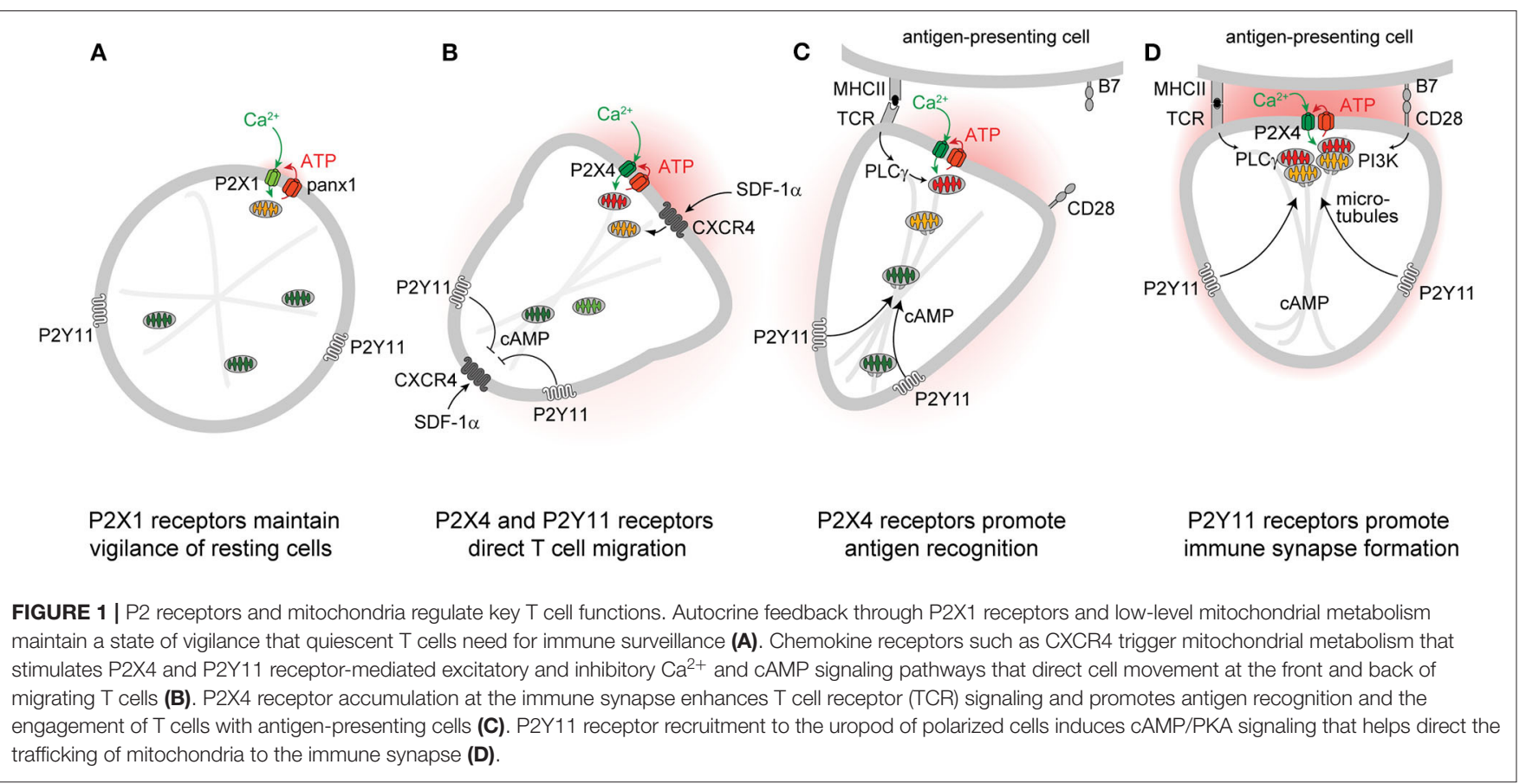

Similar mitochondrial/purinergic feedback loops also orchestrate the migration of other immune cell subtypes (5458). Like $\mathrm{T}$ cells, neutrophils depend on excitatory purinergic receptors, panx1 channels, and mitochondria to coordinate different aspects of their migration in chemotactic gradient fields $(6,55)$. However, neutrophils differ from T cells in that P2Y2 receptors rather than $\mathrm{P} 2 \mathrm{X} 4$ receptors amplify the chemotactic signals that direct cell migration at their leading edge $(6,54)$. Microglia, macrophages, and dendritic cells also depend on autocrine feedback mechanisms and specific purinergic receptors to regulate cell migration (56-58). Recent studies have shown that inhibition of the mitochondrial electron transport chain impairs the motility of neutrophils in zebrafish (59). Thus, mitochondrial metabolism and purinergic signaling seem to be preserved features that regulate immune cell migration in humans and other vertebrates.

\section{P2Y11 RECEPTORS CONTRIBUTE TO T CELL MIGRATION BY RESTRAINING MITOCHONDRIAL METABOLISM}

According to the local excitation-global inhibition (LEGI) model of chemotaxis, excitatory mechanisms at the front elicit cell protrusion, while inhibitory mechanisms at the back promote the retraction of the cell body during cell migration (60-62). In neutrophils, P2Y2 receptors provide the excitatory signal at the front, while A2a adenosine receptors generate the inhibitory cAMP/PKA signal that causes cell retraction at the back of cells (63). In T cells, P2X4 and P2Y11 receptors fulfill similar roles in the regulation of cell migration $(12,64)$. Like the A2a receptors of neutrophils, the P2Y11 receptors of T cells can couple to $G \alpha_{s}$ proteins that trigger cAMP/PKA signaling pathways (65). P2Y11 receptors bind their natural ligand, $\mathrm{ATP}$, with a reported $\mathrm{EC}_{50}$ value of 2.5 to $63 \mu \mathrm{M}$, which is similar to the affinity of P2X4 receptors (41). Therefore, the pericellular ATP that surrounds stimulated $\mathrm{T}$ cells can trigger both $\mathrm{P} 2 \mathrm{X} 4$ receptor-mediated $\mathrm{Ca}^{2+}$ influx and P2Y11 receptor-mediated cAMP/PKA signaling that restrains excitatory signaling and transduction pathways downstream of $\mathrm{G} \alpha_{\mathrm{i} / \mathrm{o}}$-coupled GPCRs like CXCR4 $(66,67)$. We found that $\mathrm{P} 2 \mathrm{Y} 11$ receptors redistribute to the back of polarized $\mathrm{T}$ cells where they induce cAMP/PKA signaling events that stabilize cell polarization by locally restricting cell stimulation by CXCR4 chemokine receptors at the back (Figure 1B) (64). Thus, $\mathrm{P} 2 \mathrm{X} 4$ and $\mathrm{P} 2 \mathrm{Y} 11$ receptors synergize to regulate mitochondrial metabolism and provide $\mathrm{T}$ cells with the local excitation and global inhibition cues that organize pseudopod protrusion and uropod retraction during $\mathrm{T}$ cell migration in a LEGI-type fashion.

\section{P2Y11 AND P2X4 RECEPTORS ORCHESTRATE THE ACCUMULATION AND ACTIVATION OF MITOCHONDRIA AT THE IMMUNE SYNAPSE OF T CELLS}

T cells must interact with APCs in order to mount immune responses. These interactions occur via organized structures referred to as immune synapses (IS) that consist of microclusters containing T cell receptors (TCR), CD3, CD28 co-receptors, LAT, SLP76, LFA-1, microtubules, and other cytoskeletal components (68). The formation of a stable IS between a $\mathrm{T}$ cell and an APC enables sustained TCR signaling that culminates in cytokine production and T cell proliferation (69). Efficient T cell activation also depends on sustained $\mathrm{Ca}^{2+}$ influx from the extracellular space (70). Just minutes after TCR stimulation, $\mathrm{P} 2 \mathrm{X} 4$ receptors, panx 1 channels, and mitochondria accumulate at 
the IS where mitochondria generate the ATP that panxl channels release into the synaptic cleft to stimulate $\mathrm{P} 2 \mathrm{X} 4$ receptormediated $\mathrm{Ca}^{2+}$ influx $(36,71,72)$. P2X4 receptors deliver the $\mathrm{Ca}^{2+}$ that mitochondria need to synthesize ATP via oxidative phosphorylation (73). However, mitochondria also act as $\mathrm{Ca}^{2+}$ sinks that fine-tune cytosolic $\mathrm{Ca}^{2+}$ levels for efficient $\mathrm{T}$ cell activation (74). Thus, mitochondria, panx1, and $\mathrm{P} 2 \mathrm{X} 4$ receptors represent a powerful feedforward signaling system that triggers downstream pathways that involve mitogen-activated protein kinases (MAPKs) and nuclear factors of activated T cells (NFAT) and induce IL-2 transcription and T cell proliferation $(10,11,36)$.

Successful T cell activation depends on the accumulation of mitochondria at the IS $(71,72,75)$. However, the mechanisms that orchestrate mitochondrial trafficking to the IS are not clear (76). In neurons, kinesin and dynein motors accomplish anterograde and retrograde trafficking of mitochondria along microtubules (77). In $\mathrm{T}$ cells, dynein facilitates mitochondrial transport to contact sites that $\mathrm{T}$ cells form with endothelial cells during their transmigration across blood vessel walls (78). Dynamin-related protein 1 (DRP1) is a mitochondrial fission factor that helps direct mitochondria to the uropod of migrating T cells and to the IS during APC engagement $(45,75)$. In neurons, cAMP promotes directional movement of mitochondria along the microtubule network (79-82), while local cytosolic $\mathrm{Ca}^{2+}$ hotspots act as mitochondrial stop signals (83). Our recent work has shown that $\mathrm{P} 2 \mathrm{Y} 11$ receptors promote trafficking of mitochondria to the IS of $\mathrm{T}$ cells (84). Thus, P2Y11 and $\mathrm{P} 2 \mathrm{X} 4$ receptors jointly recruit and activate mitochondria at the IS in order to sustain $\mathrm{T}$ cell activation. However, further studies are needed to reveal the detailed mechanisms by which these purinergic receptors, motor proteins, and the microtubule network regulate the complex process that energizes the IS in T cells (Figures 1C,D).

Several lines of evidence indicate that purinergic signaling has important physiological implications for in vivo $\mathrm{T}$ cell functions. Consistent with the critical roles of $\mathrm{P} 2 \mathrm{X}$ receptors in T cells, genetic variants of $\mathrm{P} 2 \mathrm{X} 4$ and $\mathrm{P} 2 \mathrm{X} 7$ receptors were found to contribute to multiple sclerosis, a $\mathrm{T}$ cell-mediated inflammatory autoimmune disease (85). Furthermore, CD4 T cell infiltration into the spinal cord of mice subjected to experimental autoimmune encephalomyelitis is attenuated in Panx1 knockout mice (53). The significance of P2Y11 receptors as regulators of human immune responses is supported by recent findings that single nucleotide polymorphisms (SNPs) in the $\mathrm{P} 2 \mathrm{Y} 11$ receptor gene are associated with inflammatory disorders that increase the risk of acute myocardial infarction and predispose patients to narcolepsy and reduced $\mathrm{T}$ cell viability $(86,87)$.

\section{SYSTEMIC ATP ACCUMULATION IMPAIRS IMMUNE CELL FUNCTIONS BY INTERFERING WITH THEIR AUTOCRINE PURINERGIC SIGNALING MECHANISMS}

$\mathrm{T}$ cells travel to lymphoid organs and other host tissues where they interact with APCs in order to elicit effector functions needed for host defense. As outlined above, $\mathrm{T}$ cell

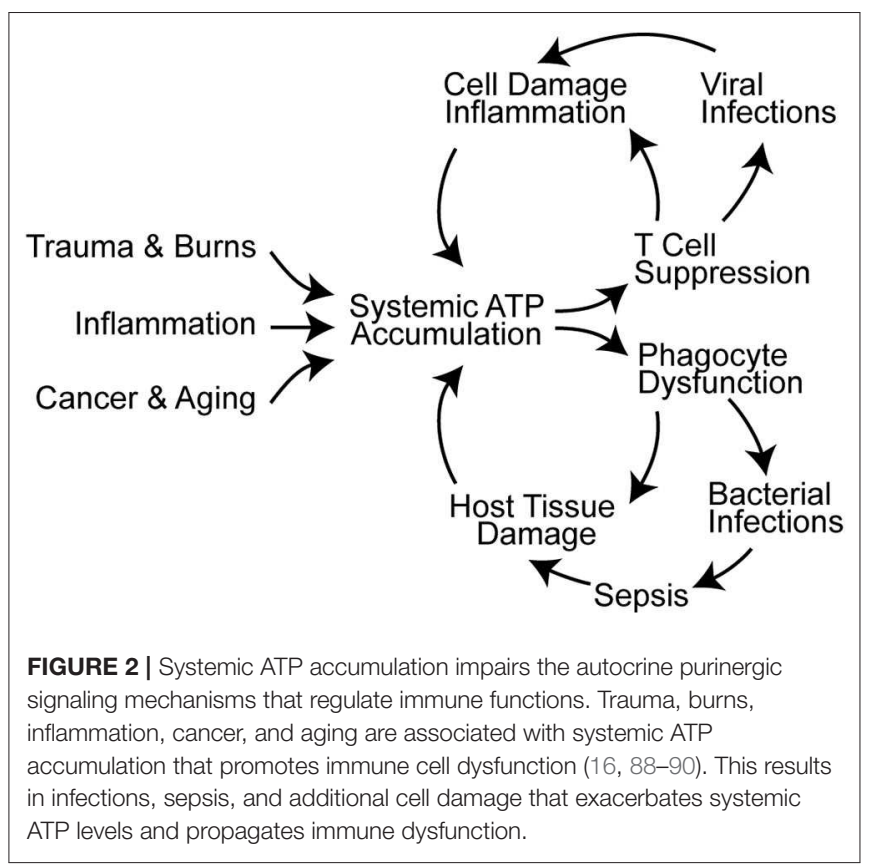

functions depend on intricate autocrine signaling mechanisms to execute their roles in host defense. However, these autocrine signaling mechanisms are susceptible to paracrine interference by exogenous ATP that accumulates in response to cell damage, tissue injury, or inflammation. Systemic ATP levels also increase in sepsis and in the tumor microenvironment, which impairs $\mathrm{T}$ cell migration, cytokine production, and $\mathrm{T}$ cell proliferation (Figure 2) (16, 88, 91-93). Global and disproportionate stimulation of P2X1, P2X4, and P2Y11 receptors across the cell surface disrupts the spatiotemporal sequence of the autocrine purinergic signaling events that regulate $\mathrm{T}$ cells and host immune functions $(64,94)$.

Besides P2X1 and P2X4 receptors, $\mathrm{T}$ cells also express the $\mathrm{P} 2 \mathrm{X} 7$ receptor subtype. $\mathrm{P} 2 \mathrm{X} 7$ receptors are comparatively insensitive to ATP with an $\mathrm{EC}_{50}$ value of $\sim 780 \mu \mathrm{M}$ (41). Interestingly, $\mathrm{P} 2 \mathrm{X} 7$ receptors remain uniformly distributed across the cell surface of $\mathrm{T}$ cells even during IS formation with APCs (36). This suggests that P2X7 receptors may act primarily as mediators of paracrine rather than autocrine ATP signaling. P2X7 receptor stimulation by external ATP can alter the composition of $\mathrm{T}$ cell subpopulations by promoting the Th1/Th17 differentiation of CD4 T cells, the conversion of immunosuppressive regulatory $\mathrm{T}$ cells $\left(\mathrm{T}_{\text {regs }}\right)$ into proinflammatory Th17 cells, and the formation of long-lived CD8 memory T cell subsets $(37,95)$. However, P2X7 receptors may also contribute to the onset of autoimmune diseases such as type 1 diabetes, namely by enhancing the activation of autoreactive CD8 effector T cells (96). P2X7 receptors differ from other purinergic receptors in that they form large and unselective macropores in response to millimolar ATP concentrations, which ultimately results in cell death (33). Physiologically, this enables $\mathrm{P} 2 \mathrm{X} 7$ receptors to control $\mathrm{T}$ follicular helper (Tfh) cell numbers in Peyer's patches of the small intestine and to modulate the 
production of IgA that shapes the gut microbiota composition (97). P2X7 receptor stimulation also limits the expansion of autoreactivity-promoting Tfh cells, whereas Tfh cells that respond to cognate antigens are protected from $\mathrm{P} 2 \mathrm{X} 7$ receptormediated cell death (97-99). On the other hand, P2X7 receptormediated cell death may also contribute to the suppression of $\mathrm{T}$ cell immunity in the presence of pathologically elevated systemic ATP levels.

Excessive ATP in the systemic environment of neutrophils has similarly disruptive implications on cell functions. Overstimulation of excitatory P2Y2 receptors disrupts neutrophil chemotaxis and bacterial clearance. At the same time, excessive P2Y2 receptor stimulation by systemic ATP aggravates inflammatory neutrophil responses such as oxidative burst and degranulation, which culminate a in neutrophil-mediated collateral host tissue damage (Figure 2) (100-102). Systemic ATP may have a similar impact on other immune cells including macrophages that depend on P2X4 and P2X7 receptors for bacterial clearance in polymicrobial sepsis $(103,104)$. Targeting extracellular ATP could be a promising approach to overcome systemic inflammation and immunosuppression in critical care and cancer patients. The therapeutic potential of this approach is supported by observations that treatment with apyrase and other enzymes that hydrolyze extracellular ATP can indeed improve outcome in mouse models of inflammation and sepsis $(89,102,105)$.

\section{CONCLUDING REMARKS}

Breakdown of increased systemic ATP levels can elevate extracellular adenosine concentrations. Adenosine exerts mostly

\section{REFERENCES}

1. Burnstock G. Purinergic nerves. Pharmacol Rev. (1972) 24:509-81.

2. Burnstock G, Knight GE. Cellular distribution and functions of P2 receptor subtypes in different systems. Int Rev Cytol. (2004) 240:31304. doi: 10.1016/S0074-7696(04)40002-3

3. Burnstock G, Fredholm BB, North RA, Verkhratsky A. The birth and postnatal development of purinergic signalling. Acta Physiol. (2010) 199:93147. doi: 10.1111/j.1748-1716.2010.02114.x

4. Lazarowski ER. Vesicular and conductive mechanisms of nucleotide release. Purinergic Signal. (2012) 8:359-73. doi: 10.1007/s11302-012-9304-9

5. Taruno A. ATP release channels. Int $J$ Mol Sci. (2018) 19:E808.doi: 10.3390/ijms19030808

6. Chen Y, Yao Y, Sumi Y, Li A, To UK, Elkhal A, et al. Purinergic signaling: a fundamental mechanism in neutrophil activation. Sci Signal. (2010) 3:ra45. doi: 10.1126/scisignal.2000549

7. Yang D, He Y, Muñoz-Planillo R, Liu Q, Núñez G. Caspase-11 requires the pannexin-1 channel and the purinergic P2X7 pore to mediate pyroptosis and endotoxic shock. Immunity. (2015) 43:92332. doi: 10.1016/j.immuni.2015.10.009

8. Sáez PJ, Vargas P, Shoji KF, Harcha PA, Lennon-Duménil AM, Sáez JC. ATP promotes the fast migration of dendritic cells through the activity of pannexin 1 channels and P2X 7 receptors. Sci Signal. (2017) 10:eaah7107. doi: 10.1126/scisignal.aah7107

9. Lee AH, Ledderose C, Li X, Slubowski CJ, Sueyoshi K, Staudenmaier L, et al. Adenosine triphosphate release is required for toll-like receptor-induced monocyte/macrophage activation, inflammasome signaling, interleukin-1 $\beta$ anti-inflammatory effects through $\mathrm{A} 2 \mathrm{a}$ and $\mathrm{A} 2 \mathrm{~b}$ receptors. While adenosine can protect tissues from inflammatory damage, excessive adenosine signaling contributes to immunosuppression in cancer and sepsis (106). The suppressive effect of A2a receptor stimulation on various $\mathrm{T}$ cell functions has been studied in great detail in mice (107). CD39 and CD73 are dominant enzymes responsible for the conversion of ATP to adenosine. Both ectonucleotidases are highly expressed by murine $\mathrm{T}_{\text {regs }}$ that suppress $\mathrm{T}$ cell functions by generating adenosine and stimulating A2a receptors $(27,32)$. In contrast to mice, CD39 expression on human CD4 T cells is largely restricted to memory $\mathrm{T}_{\text {regs }}$ (108), and $\mathrm{T}$ cell inhibition by adenosine receptordependent pathways seems to be less important in humans than in mice (109). Interestingly, mice and other rodents do not possess P2Y11 receptors (110). Thus, mouse models cannot fully reflect human disease processes. It seems likely that A2 adenosine receptors in mice fulfill the roles of human $\mathrm{P} 2 \mathrm{Y} 11$ receptors in the regulation of $\mathrm{T}$ cell functions. These species-specific differences must be considered during the development of treatments for inflammatory, infectious, and other T cell-centered diseases such as cancer.

\section{AUTHOR CONTRIBUTIONS}

CL and WJ prepared the manuscript. All authors contributed to the article and approved the submitted version.

\section{FUNDING}

This project was supported in part by grants from the National Institutes of Health, R01 GM-136429, R01 GM-51477, R01 GM116162, R01 HD-098363, and R35 GM-136429 (to WJ). production, and the host immune response to infection. Crit Care Med. (2018) 46:e1183-e89. doi: 10.1097/CCM.0000000000003446

10. Schenk U, Westendorf AM, Radaelli E, Casati A, Ferro M, Fumagalli M, et al. Purinergic control of T cell activation by ATP released through pannexin-1 hemichannels. Sci Signal. (2008) 1:ra66. doi: 10.1126/scisignal.1160583

11. Yip L, Woehrle T, Corriden R, Hirsh M, Chen Y, Inoue Y, et al. Autocrine regulation of T-cell activation by ATP release and $\mathrm{P} 2 \mathrm{X} 7$ receptors. FASEB J. (2009) 23:1685-93. doi: 10.1096/fj.08-126458

12. Ledderose C, Liu K, Kondo Y, Slubowski CJ, Dertnig T, Denicoló S, et al. Purinergic $\mathrm{P} 2 \mathrm{X} 4$ receptors and mitochondrial ATP production regulate T cell migration. J Clin Invest. (2018) 128:3583-94. doi: 10.1172/JCI120972

13. Elliott MR, Chekeni FB, Trampont PC, Lazarowski ER, Kadl A, Walk SF, et al. Nucleotides released by apoptotic cells act as a find-me signal to promote phagocytic clearance. Nature. (2009) 461:282-6. doi: 10.1038/nature0 8296

14. Di Virgilio F, Boeynaems JM, Robson SC. Extracellular nucleotides as negative modulators of immunity. Curr Opin Pharmacol. (2009) 9:50713. doi: 10.1016/j.coph.2009.06.021

15. Eltzschig HK, Sitkovsky MV, Robson SC. Purinergic signaling during inflammation. $N$ Engl J Med. (2012) 367:232233. doi: 10.1056/NEJMra1205750

16. Idzko M, Ferrari D, Eltzschig HK. Nucleotide signalling during inflammation. Nature. (2014) 509:310-17. doi: 10.1038/nature13085

17. Burnstock G, Boeynaems J-M. Purinergic signalling and immune cells. Purinergic Signal. (2014) 10:529-64. doi: 10.1007/s11302-014-9427-2

18. Ralevic V, Burnstock G. Receptors for purines and pyrimidines. Pharmacol Rev. (1998) 50:413-92. 
19. North RA. Molecular physiology of P2X receptors. Physiol Rev. (2002) 82:1013-67. doi: 10.1152/physrev.00015.2002

20. Fredholm BB, IJzerman AP, Jacobson KA, Linden J, Müller CE. International Union of Basic and Clinical Pharmacology. LXXXI. Nomenclature and classification of adenosine receptors-an update. Pharmacol Rev. (2011) 63:134. doi: 10.1124 /pr.110.003285

21. Abbracchio MP, Burnstock G, Boeynaems JM, Barnard EA, Boyer JL, Kennedy $\mathrm{C}$, et al. International Union of Pharmacology LVIII: update on the P2Y G protein-coupled nucleotide receptors: from molecular mechanisms and pathophysiology to therapy. Pharmacol Rev. (2006) 58:281341. doi: $10.1124 /$ pr.58.3.3

22. Bours MJ, Swennen EL, Di Virgilio F, Cronstein BN, Dagnelie PC. Adenosine 5'triphosphate and adenosine as endogenous signaling molecules in immunity and inflammation. Pharmacol Ther. (2006) 112:358-404. doi: 10.1016/j.pharmthera.2005.04.013

23. Zimmermann H. Extracellular metabolism of ATP and other nucleotides. Naunyn Schmiedebergs Arch Pharmacol. (2000) 362:299-309. doi: 10.1007/s002100000309

24. Robson SC, Sévigny J, Zimmermann H. The E-NTPDase family of ectonucleotidases: Structure function relationships and pathophysiological significance. Purinergic Signal. (2006) 2:409-30. doi: 10.1007/s11302-006-9003-5

25. Yegutkin GG. Nucleotide- and nucleoside-converting ectoenzymes: Important modulators of purinergic signalling cascade. Biochim Biophys Acta. (2008) 1783:673-94. doi: 10.1016/j.bbamcr.2008.01.024

26. Antonioli L, Pacher P, Vizi ES, Haskó G. CD39 and CD73 in immunity and inflammation. Trends Mol Med. (2013) 19:355-67. doi: 10.1016/j.molmed.2013.03.005

27. Deaglio S, Dwyer KM, Gao W, Friedman D, Usheva A, Erat A, et al. Adenosine generation catalyzed by $\mathrm{CD} 39$ and CD73 expressed on regulatory T cells mediates immune suppression. J Exp Med. (2007) 204:125765. doi: $10.1084 /$ jem. 20062512

28. Young JD, Yao SY, Baldwin JM, Cass CE, Baldwin SA. The human concentrative and equilibrative nucleoside transporter families, SLC28 and SLC29. Mol Aspects Med. (2013) 34:529-47. doi: 10.1016/j.mam.2012.05.007

29. Junger WG. Immune cell regulation by autocrine purinergic signalling. Nat Rev Immunol. (2011) 11:201-12. doi: 10.1038/nri2938

30. Di Virgilio F, Vuerich M. Purinergic signaling in the immune system. Auton Neurosci. (2015) 191:117-23. doi: 10.1016/j.autneu.2015.04.011

31. Cekic C, Linden J. Purinergic regulation of the immune system. Nat Rev Immunol. (2016) 16:177-92. doi: 10.1038/nri.2016.4

32. Takenaka MC, Robson S, Quintana FJ. Regulation of the $\mathrm{T}$ cell response by CD39. Trends Immunol. (2016) 37:427-39. doi: 10.1016/j.it.2016.04.009

33. Di Virgilio F, Sarti AC, Grassi F. Modulation of innate and adaptive immunity by P2X ion channels. Curr Opin Immunol. (2018) 52:519. doi: 10.1016/j.coi.2018.03.026

34. Wang L, Jacobsen SE, Bengtsson A, Erlinge D. P2 receptor mRNA expression profiles in human lymphocytes, monocytes and $\mathrm{CD} 34^{+}$stem and progenitor cells. BMC Immunol. (2004) 5:16. doi: 10.1186/1471-2172-5-16

35. Jacob F, Pérez Novo C, Bachert C, Van Crombruggen K. Purinergic signaling in inflammatory cells: P2 receptor expression, functional effects, and modulation of inflammatory responses. Purinergic Signal. (2013) 9:285306. doi: 10.1007/s11302-013-9357-4

36. Woehrle T, Yip L, Elkhal A, Sumi Y, Chen Y, Yao Y, et al. Pannexin-1 hemichannel-mediated ATP release together with P2X1 and P2X4 receptors regulate T-cell activation at the immune synapse. Blood. (2010) 116:347584. doi: 10.1182/blood-2010-04-277707

37. Schenk U, Frascoli M, Proietti M, Geffers R, Traggiai E, Buer J, et al. ATP inhibits the generation and function of regulatory $\mathrm{T}$ cells through the activation of purinergic P2X receptors. Sci Signal. (2011) 4:ra12. doi: 10.1126/scisignal.2001270

38. Trabanelli S, Ocadlíková D, Gulinelli S, Curti A, Salvestrini V, Vieira RP, et al. Extracellular ATP exerts opposite effects on activated and regulatory $\mathrm{CD}^{+} \mathrm{T}$ cells via purinergic P2 receptor activation. J Immunol. (2012) 189:1303-10. doi: 10.4049/jimmunol.1103800

39. Wang CM, Ploia C, Anselmi F, Sarukhan A, Viola A. Adenosine triphosphate acts as a paracrine signaling molecule to reduce the motility of T cells. EMBO J. (2014) 33:1354-64. doi: 10.15252/embj.201386666
40. Dreisig K, Sund L, Dommer MW, Kristensen NP, Boddum K, Viste R, et al. Human $\mathrm{P}_{2} \mathrm{Y}_{11}$ expression level affects human P2X7 receptor-mediated cell death. Front Immunol. (2018) 9:1159. doi: 10.3389/fimmu.2018.01159

41. Jacobson KA, Jarvis MF, Williams M. Purine and pyrimidine (P2) receptors as drug targets. J Med Chem. (2002) 45:4057-93. doi: 10.1021/jm020046y

42. Yegutkin GG, Mikhailov A, Samburski SS, Jalkanen S. The detection of micromolar pericellular ATP pool on lymphocyte surface by using lymphoid ecto-adenylate kinase as intrinsic ATP sensor. Mol Biol Cell. (2006) 17:337885. doi: 10.1091/mbc.e05-10-0993

43. Adinolfi E, Callegari MG, Ferrari D, Bolognesi C, Minelli M, Wieckowski MR, et al. Basal activation of the P2X7 ATP receptor elevates mitochondrial calcium and potential, increases cellular ATP levels, and promotes serum-independent growth. Mol Biol Cell. (2005) 16:3260-72. doi: 10.1091/mbc.e04-11-1025

44. Ledderose C, Bao Y, Ledderose S, Woehrle T, Heinisch M, Yip L, et al. Mitochondrial dysfunction, depleted purinergic signaling, and defective $\mathrm{T}$ cell vigilance and immune defense. J Infect Dis. (2016) 213:45664. doi: 10.1093/infdis/jiv373

45. Campello S, Lacalle RA, Bettella M, Mañes S, Scorrano L, Viola A. Orchestration of lymphocyte chemotaxis by mitochondrial dynamics. J Exp Med. (2006) 203:2879-86. doi: 10.1084/jem.20061877

46. Belikova I, Lukaszewicz AC, Faivre V, Damoisel C, Singer M, Payen D. Oxygen consumption of human peripheral blood mononuclear cells in severe human sepsis. Crit Care Med. (2007) 35:2702-8. doi: 10.1097/01.ccm.0000295593.25106.c4

47. Japiassú AM, Santiago AP, d'Avila JC, Garcia-Souza LF, Galina A, Castro Faria-Neto HC, et al. Bioenergetic failure of human peripheral blood monocytes in patients with septic shock is mediated by reduced F1Fo adenosine-5'-triphosphate synthase activity. Crit Care Med. (2011) 39:105663. doi: 10.1097/CCM.0b013e31820eda5c

48. Cheng SC, Scicluna BP, Arts RJ, Gresnigt MS, Lachmandas E, GiamarellosBourboulis EJ, et al. Broad defects in the energy metabolism of leukocytes underlie immunoparalysis in sepsis. Nat Immunol. (2016) 17:40613. doi: $10.1038 /$ ni.3398

49. Jensen IJ, Sjaastad FV, Griffith TS, Badovinac VP. Sepsis-induced T cell immunoparalysis: the ins and outs of impaired T cell immunity. J Immunol. (2018) 200:1543-53. doi: 10.4049/jimmunol.1701618

50. Mora JR, von Andrian UH. T-cell homing specificity and plasticity: new concepts and future challenges. Trends Immunol. (2006) 27:23543. doi: 10.1016/j.it.2006.03.007

51. Masopust D, Schenkel JM. The integration of T cell migration, differentiation and function. Nat Rev Immunol. (2013) 13:309-20. doi: 10.1038/nri3442

52. Griffith JW, Sokol CL, Luster AD. Chemokines and chemokine receptors: positioning cells for host defense and immunity. Annu Rev Immunol. (2014) 32:659-702. doi: 10.1146/annurev-immunol-032713-12 0145

53. Velasquez S, Malik S, Lutz SE, Scemes E, Eugenin EA. Pannexin1 channels are required for chemokine-mediated migration of $\mathrm{CD} 4^{+} \mathrm{T}$ lymphocytes: role in inflammation and experimental autoimmune encephalomyelitis. $J$ Immunol. (2016) 196:4338-47. doi: 10.4049/jimmunol.1502440

54. Chen Y, Corriden R, Inoue Y, Yip L, Hashiguchi N, Zinkernagel A, et al. ATP release guides neutrophil chemotaxis via $\mathrm{P} 2 \mathrm{Y} 2$ and $\mathrm{A} 3$ receptors. Science. (2006) 314:1792-5. doi: 10.1126/science.1132559

55. Bao Y, Ledderose C, Graf AF, Brix B, Birsak T, Lee A, et al. mTOR and differential activation of mitochondria orchestrate neutrophil chemotaxis. $J$ Cell Biol. (2015) 210:1153-64. doi: 10.1083/jcb.201503066

56. Haynes SE, Hollopeter G, Yang G, Kurpius D, Dailey ME, Gan WB, et al. The $\mathrm{P} 2 \mathrm{Y} 12$ receptor regulates microglial activation by extracellular nucleotides. Nat Neurosci. (2006) 9:1512-9. doi: 10.1038/nn1805

57. Kronlage M, Song J, Sorokin L, Isfort K, Schwerdtle T, Leipziger J, et al. Autocrine purinergic receptor signaling is essential for macrophage chemotaxis. Sci Signal. (2010) 3:ra55. doi: 10.1126/scisignal

58. Müller T, Robaye B, Vieira RP, Ferrari D, Grimm M, Jakob T, et al. The purinergic receptor $\mathrm{P} 2 \mathrm{Y} 2$ receptor mediates chemotaxis of dendritic cells and eosinophils in allergic lung inflammation. Allergy. (2010) 65:154553. doi: 10.1111/j.1398-9995.2010.02426.x

59. Zhou W, Cao L, Jeffries J, Zhu X, Staiger CJ, Deng Q. Neutrophilspecific knockout demonstrates a role for mitochondria in 
regulating neutrophil motility in zebrafish. Dis Model Mech. (2018) 11:dmm033027. doi: 10.1242/dmm.033027

60. Ridley AJ, Schwartz MA, Burridge K, Firtel RA, Ginsberg MH, Borisy G, et al. Cell migration: integrating signals from front to back. Science. (2003) 302:1704-9. doi: 10.1126/science. 1092053

61. Janetopoulos C, Firtel RA. Directional sensing during chemotaxis. FEBS Lett. (2008) 582:2075-85. doi: 10.1016/j.febslet.2008.04.035

62. Rappel WJ, Edelstein-Keshet L. Mechanisms of cell polarization. Curr Opin Syst Biol. (2017) 3:43-53. doi: 10.1016/j.coisb.2017.03.005

63. Bao Y, Chen Y, Ledderose C, Li L, Junger WG. Pannexin 1 channels link chemoattractant receptor signaling to local excitation and global inhibition responses at the front and back of polarized neutrophils. J Biol Chem. (2013) 288:22650-7. doi: 10.1074/jbc.M113.476283

64. Ledderose C, Bromberger S, Slubowski CJ, Sueyoshi K, Aytan D, Shen $\mathrm{Y}$, et al. The purinergic receptor P2Y11 choreographs the polarization, mitochondrial metabolism, and migration of $\mathrm{T}$ lymphocytes. Sci Signal. (2020). doi: 10.1126/scisignal.aba3300. [Epub ahead of print].

65. Qi AD, Kennedy C, Harden TK, Nicholas RA. Differential coupling of the human $\mathrm{P} 2 \mathrm{Y}(11)$ receptor to phospholipase $\mathrm{C}$ and adenylyl cyclase. $\mathrm{Br} \mathrm{J}$ Pharmacol. (2001) 132:318-26. doi: 10.1038/sj.bjp.0703788

66. Häfner S, Adler HS, Mischak H, Janosch P, Heidecker G, Wolfman A, et al. Mechanism of inhibition of Raf-1 by protein kinase A. Mol Cell Biol. (1994) 14:6696-703. doi: 10.1128/mcb.14.10.6696

67. Houslay MD, Kolch W. Cell-type specific integration of cross-talk between extracellular signal-regulated kinase and cAMP signaling. Mol Pharmacol. (2000) 58:659-68. doi: 10.1124/mol.58.4.659

68. Dustin ML, Choudhuri K. Signaling and polarized communication across the T cell immunological synapse. Annu Rev Cell Dev Biol. (2016) 32:30325. doi: 10.1146/annurev-cellbio-100814-125330

69. Billadeau DD, Nolz JC, Gomez TS. Regulation of T-cell activation by the cytoskeleton. Nat Rev Immunol. (2007) 7:131-43. doi: 10.1038/nri2021

70. Trebak M, Kinet JP. Calcium signalling in T cells. Nat Rev Immunol. (2019) 19:154-69. doi: 10.1038/s41577-018-0110-7

71. Quintana A, Schwindling C, Wenning AS, Becherer U, Rettig J, Schwarz EC, et al. T cell activation requires mitochondrial translocation to the immunological synapse. Proc Natl Acad Sci USA. (2007) 104:1441823. doi: $10.1073 /$ pnas. 0703126104

72. Ledderose C, Bao Y, Lidicky M, Zipperle J, Li L, Strasser K, et al. Mitochondria are gate-keepers of $\mathrm{T}$ cell function by producing the ATP that drives purinergic signaling. J Biol Chem. (2014) 289:2593645. doi: $10.1074 /$ jbc.M114.575308

73. Glancy B, Balaban RS. Role of mitochondrial Ca2+ in the regulation of cellular energetics. Biochemistry. (2012) 51:2959-73. doi: 10.1021/bi2018909

74. Quintana A, Pasche M, Junker C, Al-Ansary D, Rieger H, Kummerow C, et al. Calcium microdomains at the immunological synapse: how ORAI channels, mitochondria and calcium pumps generate local calcium signals for efficient T-cell activation. EMBO J. (2011) 30:3895-912. doi: 10.1038/emboj.2011.289

75. Baixauli F, Martín-Cófreces NB, Morlino G, Carrasco YR, Calabia-Linares $\mathrm{C}$, Veiga E, et al. The mitochondrial fission factor dynamin-related protein 1 modulates T-cell receptor signalling at the immune synapse. EMBO J. (2011) 30:1238-50. doi: 10.1038/emboj.2011.25

76. Martín-Cófreces NB, Sánchez-Madrid F. Sailing to and docking at the immune synapse: role of tubulin dynamics and molecular motors. Front Immunol. (2018) 9:1174. doi: 10.3389/fimmu.2018.01174

77. Barnhart EL. Mechanics of mitochondrial motility in neurons. Curr Opin Cell Biol. (2016) 38:90-9. doi: 10.1016/j.ceb.2016.02.022

78. Morlino G, Barreiro O, Baixauli F, Robles-Valero J, González-Granado JM, Villa-Bellosta R, et al. Miro-1 links mitochondria and microtubule dynein motors to control lymphocyte migration and polarity. Mol Cell Biol. (2014) 34:1412-26. doi: 10.1128/MCB.01177-13

79. Müller M, Mironov SL, Ivannikov MV, Schmidt J, Richter DW. Mitochondrial organization and motility probed by two-photon microscopy in cultured mouse brainstem neurons. Exp Cell Res. (2005) 303:11427. doi: 10.1016/j.yexcr.2004.09.025

80. Ogawa F, Murphy LC, Malavasi EL, O'Sullivan ST, Torrance HS, Porteous DJ, et al. NDE1 and GSK3 $\beta$ associate with TRAK1 and regulate axonal mitochondrial motility: identification of cyclic AMP as a novel modulator of axonal mitochondrial trafficking. ACS Chem Neurosci. (2016) 7:55364. doi: 10.1021/acschemneuro.5b00255

81. Das Banerjee T, Dagda RY, Dagda M, Chu CT, Rice M, VazquezMayorga E, et al. PINK1 regulates mitochondrial trafficking in dendrites of cortical neurons through mitochondrial PKA. J Neurochem. (2017) 142:54559. doi: $10.1111 /$ jnc. 14083

82. Vagnoni A, Bullock SL. A cAMP/PKA/kinesin-1 axis promotes the axonal transport of mitochondria in aging drosophila neurons. Curr Biol. (2018) 28:1265-72 doi: 10.1016/j.cub.2018.02.048

83. Wang $\mathrm{X}$, Schwarz TL. The mechanism of $\mathrm{Ca}^{2+}$-dependent regulation of kinesin-mediated mitochondrial motility. Cell. (2009) 136:163-74. doi: 10.1016/j.cell.2008.11.046

84. Ledderose C, Bromberger S, Slubowski CJ, Sueyoshi K, Junger WG. Frontline Science: P2Y11 receptors support $\mathrm{T}$ cell activation by directing mitochondrial trafficking to the immune synapse. J Leukoc Biol. (2020). doi: 10.1002/JLB.2HI0520-191R. [Epub ahead of print].

85. Sadovnick AD, Gu BJ, Traboulsee AL, Bernales CQ, Encarnacion M, Yee IM, et al. Purinergic receptors P2RX4 and P2RX7 in familial multiple sclerosis. Hum Mutat. (2017) 38:736-44. doi: 10.1002/humu.23218

86. Amisten S, Melander O, Wihlborg AK, Berglund G, Erlinge D. Increased risk of acute myocardial infarction and elevated levels of C-reactive protein in carriers of the Thr-87 variant of the ATP receptor P2Y11. Eur Heart J. (2007) 28:13-8. doi: 10.1093/eurheartj/ehl410

87. Kornum BR, Kawashima M, Faraco J, Lin L, Rico TJ, Hesselson S, et al. Common variants in P2RY11 are associated with narcolepsy. Nat Genet. (2011) 43:66-71. doi: 10.1038/ng.734

88. Di Virgilio F, Sarti AC, Falzoni S, De Marchi E, Adinolfi E. Extracellular ATP and P2 purinergic signalling in the tumour microenvironment. Nat Rev Cancer. (2018) 18:601-18. doi: 10.1038/s41568-018-0037-0

89. Cauwels A, Rogge E, Vandendriessche B, Shiva S, Brouckaert P. Extracellular ATP drives systemic inflammation, tissue damage and mortality. Cell Death Dis. (2014) 5:e1102. doi: 10.1038/cddis.2014.70

90. Lawton KA, Berger A, Mitchell M, Milgram KE, Evans AM, Guo L, et al. Analysis of the adult human plasma metabolome. Pharmacogenomics. (2008) 94:383-97. doi: 10.2217/14622416.9.4.383

91. Sumi Y, Woehrle T, Chen Y, Bao Y, Li X, Yao Y, et al. Plasma ATP is required for neutrophil activation in a mouse sepsis model. Shock. (2014) 42:142-7. doi: 10.1097/SHK.0000000000000180

92. Weiler M, Schmetzer H, Braeu M, Buhmann R. Inhibitory effect of extracellular purine nucleotide and nucleoside concentrations on $\mathrm{T}$ cell proliferation. Exp Cell Res. (2016) 349:1-14. doi: 10.1016/j.yexcr.2016.05.017

93. Shinohara $\mathrm{Y}$, Tsukimoto $\mathrm{M}$. Adenine nucleotides attenuate murine $\mathrm{T}$ cell activation induced by concanavalin A or T cell receptor stimulation. Front Pharmacol. (2018) 8:986. doi: 10.3389/fphar.2017.00986

94. Sueyoshi K, Ledderose C, Shen Y, Lee AH, Shapiro NI, Junger WG. Lipopolysaccharide suppresses $\mathrm{T}$ cells by generating extracellular ATP that impairs their mitochondrial function via P2Y11 receptors.J Biol Chem. (2019) 294:6283-93. doi: 10.1074/jbc.RA118.007188

95. Borges da Silva H, Beura LK, Wang H, Hanse EA, Gore R, Scott MC, et al. The purinergic receptor P2RX7 directs metabolic fitness of long-lived memory $\mathrm{CD}^{+}$T cells. Nature. (2018) 559:264-8. doi: 10.1038/s41586-018-0282-0

96. Tezza S, Ben Nasr M, D’Addio F, Vergani A, Usuelli V, Falzoni S, et al. Isletderived eATP fuels autoreactive $\mathrm{CD} 8^{+} \mathrm{T}$ cells and facilitates the onset of type 1 diabetes. Diabetes. (2018) 67:2038-53. doi: 10.2337/db17-1227

97. Proietti M, Cornacchione V, Rezzonico Jost T, Romagnani A, Faliti CE, Perruzza L, et al. ATP-gated ionotropic P2X7 receptor controls follicular $\mathrm{T}$ helper cell numbers in Peyer's patches to promote host-microbiota mutualism. Immunity. (2014) 41:789-801. doi: 10.1016/j.immuni.2014.10.01

98. Faliti CE, Gualtierotti R, Rottoli E, Gerosa M, Perruzza L, Romagnani A, et al. P2X7 receptor restrains pathogenic Tfh cell generation in systemic lupus erythematosus. J Exp Med. (2019) 216:317-36. doi: 10.1084/jem.20171976

99. Grassi F. The P2X7 receptor as regulator of T cell development and function. Front Immunol. (2020) 11:1179. doi: 10.3389/fimmu.2020.01179

100. Wang X, Qin W, Xu X, Xiong Y, Zhang Y, Zhang H, et al. Endotoxininduced autocrine ATP signaling inhibits neutrophil chemotaxis through enhancing myosin light chain phosphorylation. Proc Natl Acad Sci USA. (2017) 114:4483-8. doi: 10.1073/pnas.1616752114 
101. Kondo Y, Ledderose C, Slubowski CJ, Fakhari M, Sumi Y, Sueyoshi K, et al. Frontline Science: Escherichia coli use LPS as decoy to impair neutrophil chemotaxis and defeat antimicrobial host defense. J Leukoc Biol. (2019) 106:1211-19. doi: 10.1002/JLB.4HI0319-109R

102. Li X, Kondo Y, Bao Y, Staudenmaier L, Lee A, Zhang J, et al. Systemic adenosine triphosphate impairs neutrophil chemotaxis and host defense in sepsis. Crit Care Med. (2017) 45:e97-e104. doi: 10.1097/CCM.0000000000002052

103. Csóka B, Németh ZH, Töro G, Idzko M, Zech A, Koscsó B, et al. Extracellular ATP protects against sepsis through macrophage $\mathrm{P} 2 \mathrm{X} 7$ purinergic receptors by enhancing intracellular bacterial killing. FASEB J. (2015) 29:362637. doi: $10.1096 / f j .15-272450$

104. Csóka B, Németh ZH, Szabó I, Davies DL, Varga ZV, Pálóczi J, et al. Macrophage P2X4 receptors augment bacterial killing and protect against sepsis. JCI Insight. (2018) 3:e99431. doi: 10.1172/jci.insight.99431

105. Csóka B, Németh ZH, Töro G, Koscsó B, Kókai E, Robson SC, et al. CD39 improves survival in microbial sepsis by attenuating systemic inflammation. FASEB J. (2015) 29:25-36. doi: 10.1096/fj.14-253567

106. Haskó G, Pacher P. A2A receptors in inflammation and injury: lessons learned from transgenic animals. J Leukoc Biol. (2008) 83:447-55. doi: 10.1189/jlb.0607359

107. Antonioli L, Fornai M, Blandizzi C, Pacher P, Haskó G. Adenosine signaling and the immune system: When a lot could be too much. Immunol Lett. (2019) 205:9-15. doi: 10.1016/j.imlet.2018.04.006
108. Borsellino G, Kleinewietfeld M, Di Mitri D, Sternjak A, Diamantini A, Giometto R, et al. Expression of ectonucleotidase CD39 by Foxp $^{+}$Treg cells: hydrolysis of extracellular ATP and immune suppression. Blood. (2007) 110:1225-32. doi: 10.1182/blood-2006-12-0 64527

109. Schiedel AC, Lacher SK, Linnemann C, Knolle PA, Müller CE. Antiproliferative effects of selective adenosine receptor agonists and antagonists on human lymphocytes: evidence for receptor-independent mechanisms. Purinergic Signal. (2013) 9:351-65. doi: 10.1007/s11302-0139354-7

110. Kennedy C. P2Y(11) Receptors: Properties, distribution and functions. $A d v$ Exp Med Biol. (2017) 1051:107-22. doi: 10.1007/5584

Conflict of Interest: The authors declare that the research was conducted in the absence of any commercial or financial relationships that could be construed as a potential conflict of interest.

Copyright $\odot 2020$ Ledderose and Junger. This is an open-access article distributed under the terms of the Creative Commons Attribution License (CC BY). The use, distribution or reproduction in other forums is permitted, provided the original author(s) and the copyright owner(s) are credited and that the original publication in this journal is cited, in accordance with accepted academic practice. No use, distribution or reproduction is permitted which does not comply with these terms. 